\title{
РЕДКИЙ МОНОГЕННЫЙ СИНДРОМ С НИЗКОРОСЛОСТЬЮ
}

\section{(КЛИНИЧЕСКИЙ СЛУЧАЙ)}

${ }^{1}$ Гуменюк О.И., ${ }^{1 Ч е р н е н к о в ~ Ю . В ., ~}{ }^{1}$ Кулаевская М.В., ${ }^{1}$ Мишанина Д.А., ${ }^{2}$ Гусева Д.М.

${ }^{1}$ ФГБОУ ВО Саратовский государственный медицинский университет им. В.И. Разумовского МЗ РФ, г.Саратов

${ }^{2}$ ФГБНУ «Медико-генетический научный центр имени академика Н.П. Бочкова», г. Москва

Моногенные болезни - это болезни, причиной которых являются единичные или точковые генные мутации.

Представлен клинический случай пациента с редким генетическим синдромом с низкорослостью.

Мальчик, 2011 г.р. имеет следующие патологические симптомы: отягощенный перинатальный период, задержка психо-моторного, речевого развития и роста с первого года жизни, сложный гиперметропический астигматизм OU, врожденный порок развития мочевыделительной системы: Lобразная правая почка, двухсторонний мегауретер; врожденный порок сердца: двустворчатый клапан аорты; плоско- вальгусная установка стоп. При осмотре обращают на себя внимание множественные стигмы дизэмбриогенеза: двусторонний птоз век, гипертелоризм, двусторонний эпикант, низкий лоб, микростомия, готическое небо, брахидактилия с широкими I пальцами кистей и ног, гипертрихоз рук и ног, воронкообразная грудная клетка. Физическое развитие: рост 122 см, масса тела 21 кг, ИМТ 14,9 кг/м2 (25 цент), SDS роста -2,1 сигмы. Половое развитие соответствует возрасту (Tanner I). Нарушение произношения слов, ограниченный словарный запас. При дополнительных методах исследования установлены лейкоцитурия, альбуминурия до 30 мг альбумина/Г креатинина, снижение скорости клубочковой фильтрации до 93 мл/мин/1,73 м² (ХБП ІІ степени), костный возраст отстает на 2,5-3 года. Исключена патология щитовидной железы, мукополисахаридозы I,II,III,IV,VI,VII типов, болезнь Фабри, синдром Рубинштейна-Тейби. Кариотип 46, XY - нормальный мужской кариотип.

Проведено секвенирование клинического экзома (ФГБНУ МГНЦ им. Н.П. Бочкова), выявлены мутации в гене КМТ2А в гетерозиготном состоянии, что характерно для синдрома ВидеманнаШтейнера (Wiedemann-Steiner syndrome, OMIM: 605130). Происхождение выявленного варианта: de novo (При обследовании родителей подобной мутации не выявлено.

Данный клинический случай демонстрирует классическое течение моногенного заболевания, протекающего с низкорослостью и пороками развития внутренних органов. 